\title{
海岸堤防・護岸の被災限界の研究 DAMAGE LIMITATION OF A COASTAL DIKE AND A SEAWALL
}

\author{
山本吉道 1 ・成吉兼二 2 ・比嘉了規 3 \\ Yoshimichi YAMAMOTO, Ryoki HIGA, Kenji NARIYOSHI \\ 1フェロー 博 (工） 東海大学教授 大学院総合理工学研究科（テ259-1292 平塚市北金目 4-1-1） \\ 2学生会員 修(工） 東海大学 大学院総合理工学研究科（下 $259-1292$ 同上） \\ 3学生会員 東海大学 大学院工学研究科 土木工学専攻（广259-1292 同上）
}

\begin{abstract}
It is important to know the threshold of the cross-section area of a beach to which a coastal dike and a seawall will come to suffer damage. Therefore, the actual conditions on coastal damage are investigated about 33 beaches in Japan and Thailand. Then, the marginal sizes of the beach required in order that those coastal facilities will not suffer damage to each incident wave are clarified. Moreover, since there are many cases that the destructive mechanism of the dike and the seawall on a sand area or a very shallow area cannot be explained by only the stability calculations of these facilities, scour and suction also need to be taken into consideration. Hence, a practical method of predicting the destruction of the dike or the seawall by using the wave overtopping rate to it and the net effective shearing resistance force in its sucking part is proposed. In addition, the availability of a countermeasure which strengthens the net effective shearing resistance force by using small stones as material of the sucking part is confirmed.
\end{abstract}

Key Words : Coastal dike, Seawall, damage limitation, beach height, beach cross-section area, suction

\section{1.はじめに}

前浜や十分に浅い水深に設置された三面張り堤防 や二面張り護岸が，計画沖波波高より小さな来襲波 で被災した事例が多数存在する。これらの主たる原 因が侵食，洗掘，さらに吸出しによることは，大河 原ほが）などが指摘しており，岩崎ほか ${ }^{21}$ は堤防の 表のり被覆に隙間がなくても, 堤体の最下端から吸 出しが生じ破壊に至ることを大型実験で示し, 山本 ほか ${ }^{3)}$ は堤防前面の水深が $3 \mathrm{~m}$ 以浅の場合に，洗 掘・吸出しによる被災が卓越することを被災事例検 討と安定計算から示している。善 ${ }^{4)}$ は洗掘・吸出し に係る基礎理論として，海底砂地盤の波浪による液 状化予測モデルを構築し，加藤ほか $\left.{ }^{5}\right)$ は同予測モデ ルを海岸堤防に適用して，透過性を高めると吸出し 防止効果を期待できることを示している。また，前 野ほか ( $^{6)}$ などは矢板式単純護岸に対して多孔質弾性 体の浸透理論を用いた有限要素解析に基づく吸出し 予測を, 中村ほか ${ }^{7)}$ は捨石式単純護岸に対してVOFFEM改良モデルによる吸出し検討を行っている。さ らに, 山本・南8) は三面張り堤防と二面張り護岸に ついて, 洗掘が進み, 前面の砂浜が消失するように なってくると，堤体内に侵入した波による戻り流れ 時の最大せん断力が有効せん断抵抗力を超えるよう になり，堤体裏込材の吸出しが生じると考えて，水 理模型実験から両方の力の算定式を求め, 被災事例
への適用を試みている。そして，堤体吸出し部の裏 込材を透過性とせん断抵抗力の大きな砕石に置き換 えることによって吸出しを防止出来ることを示して いる.

砂浜規模がどの程度以下になれば，海岸堤防や護 岸が被災するようになるかを知ることは重要であり， 海岸堤防・護岸が被災する限界の砂浜断面諸元や来 襲波諸元との関係を求める試みが複数の公的機関で 実施されたが，我々は本研究で，タイ国での事例も 追加収集して被災限界時のこれら諸元を明らかにす る.さらに，極浅海域や砂浜上にある海岸堤防・護 岸の破壊機構は波力に対する構造物の安定計算だけ では説明出来ず，洗掘・吸出しも考慮する必要があ り, 山本・南 ${ }^{8)}$ の研究を発展させて, これらの破壊 を来襲波による越波量と正味の有効剪断抵抗力で判 断出来る実用的な方法を提案する.

\section{2. 砂浜による防災効果}

\section{（1）海岸被災実態調査}

\section{a）実態調査法}

山本ほか ${ }^{3)}$ の実態調査データ（15箇所） ，国内 で2006〜2010年に，タイ国タイ湾で2009〜2010年に 
実施した海岸被災実態調査のデータ（18箇所）を追 加し, 付録の表-1にまとめる. タイ国でも実施した 理由は, 同国でも海岸部の開発や侵食が進み, 海岸 保全問題がクローズアップされるようになってきた ことと, 日本では少ない換算沖波波高 $4 \mathrm{~m}$ 以下での 被災事例が多くあるからである. 国内の事例では管 理事務所の公開資料の入手が容易なので, 最初にこ れを収集し，不足データを現地測量やヒアリング等 で補った。 タイ国の事例では公開されている資料が ほとんど無いので, 最初に現地踏査を行い, 要所に て実測と，管理事務所や地元民へのヒアリングを 行った。ただし，潮位・波浪データはタイ国モン クット王工科大学土木工学科長が自国政府から入手 したものを使用した.

表-1において, 前面矢板下端深さ, 天端高, 浜高 さと高潮水位の基準水位には, 国内では東京湾中等 潮位を, タイ国でも極力平均潮位となるように Chaophraya川河口〜Jomthienビーチで L. L.W. L+2. 1m を, Sangchanビーチ〜Leamsadetビーチで L. L. W. L+1. 5m を用いている。

換算沖波波高には，国内では対象とした時化時の 最寄りの観測所（水深 $20 \mathrm{~m}$ 程度か, それ以深）の最 大有義波高を代用した。 タイ国の部分破壊ケースで は最近 $1 ・ 2$ 年に被災していたが， 5 年前から同国 政府によるブイ式波浪計を用いた沖合観測が中断し ているので，それ以前の沖合観測記録による年 1 回 出現頻度の有義波を用いた。同国の非破壊ケースで は最近 $1 \cdot 2$ 年間被災していなかったので, 同様に 沖合観測記録による年 1 回出現頻度の有義波を, 完 全破壞ケースでは原因となった台風 Linda の沖合 での最大有義波の推算值を用いた.

潮位には，破壊ケースでは対象とした時化時の最 大潮位を，非破壊ケースでは 1 年間の平均 H.W.L を 用いた.

\section{b）堤防・護岸が被災しないための砂浜限界諸元}

付録の表-1にまとめられたデータを用いて, 被災 事例の換算沖波波高と見なした沖合有義波高と堤 防・護岸前面の砂浜高との関係を黒丸で, 非被災事 例のそれを白丸で図-1に示した。同様に，被災事例 の同沖合有義波高と堤防・護岸前面の砂浜幅との関 係を黒丸で, 非被災事例のそれを白丸で図-2に示し た。さらに, 被災事例の同沖合有義波高 $\times$ 沖波波長 と平均潮位上の砂浜断面積（=砂浜高 $\times$ 砂浜幅 / 2）との関係を黒丸で, 非被災事例のそれを白丸で 図-3に示した。ここで，換算沖波波高として沖合有 義波高を用いた理由は, 最寄りの波浪観測所で得ら れたデータをそのまま利用出来るようにするためで ある。

図-1，2，3において，黒丸の分布域では被災する 可能性が極めて高いと判断出来る. そして, コンク リートまたは石積コンクリート被覆の堤防や護岸で は, 前面砂浜高 $0 \mathrm{~m}$ また砂浜幅 $0 \mathrm{~m}$ 場合でも沖合有 義波高 $1.5 \mathrm{~m}$ 程度まで, 前面砂浜高 $\times$ 砂浜幅 $/ 2$ が
$0 \mathrm{~m}^{2}$ の場合でも沖合有義波高 $\times$ 沖波波長が $100 \mathrm{~m}^{2}$ 程度 までならば被災しにくいことも判った。

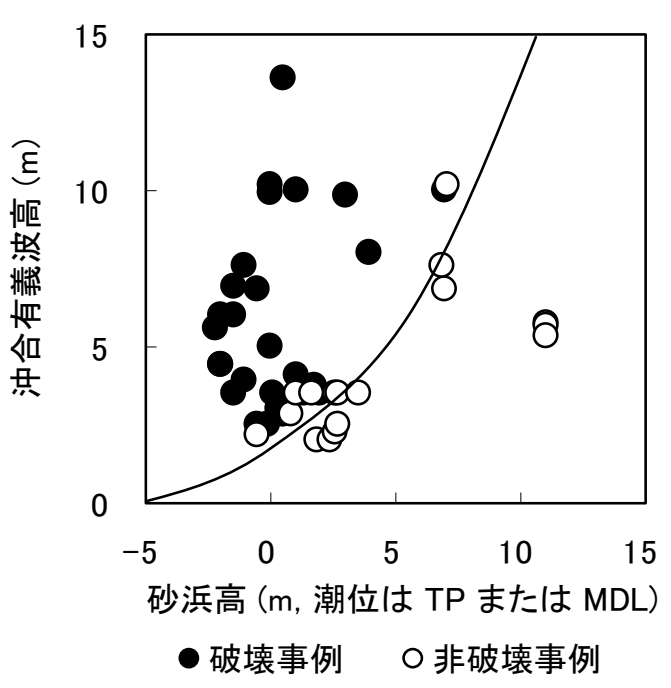

図-1 海岸堤防・護岸の破壊する限界 の砂浜高と沖合有義波高の関係

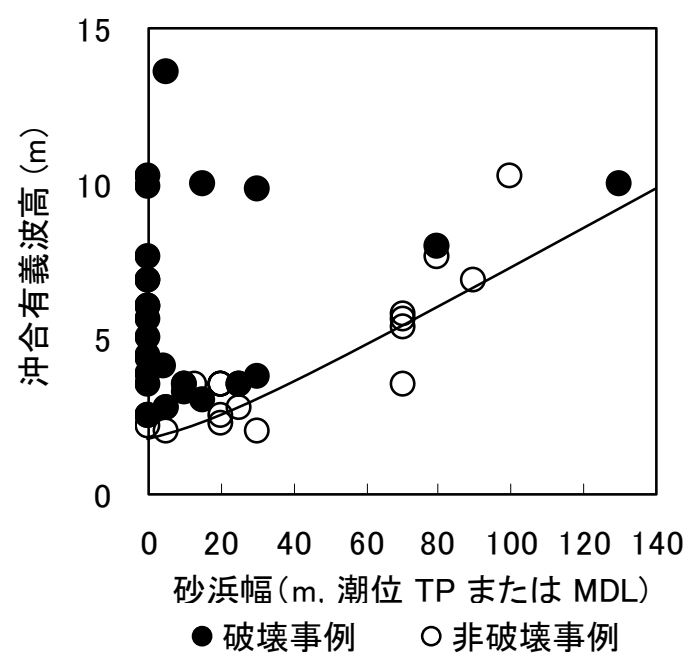

図-2 海岸堤防・護岸の破壊する限界 の砂浜幅と沖合有義波高の関係

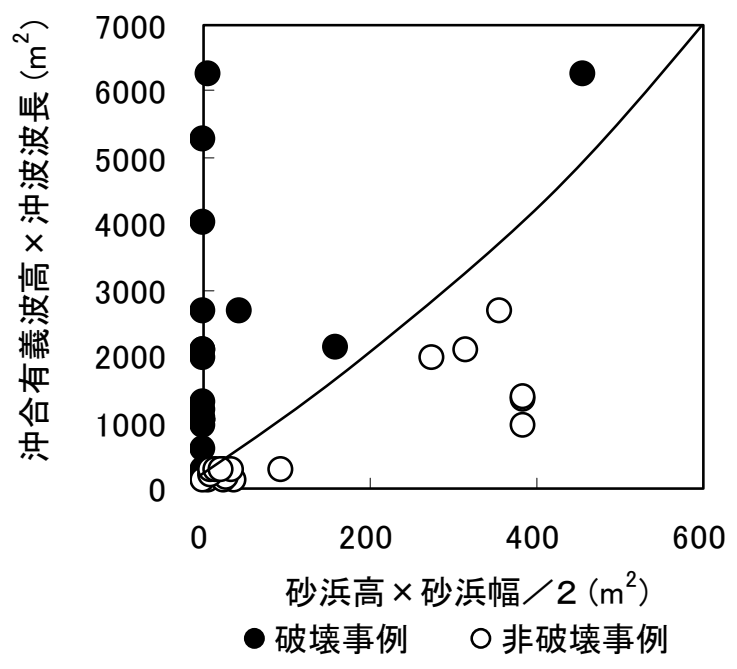

図-3 海岸堤防・護岸の破壊する限界の 砂浜断面積と沖合の有義波高 $\times$ 波長の関係 


\section{3. 吸出し被害の予測}

ここでは，三面張り堤防と二面張り護岸について, 山本・南 ${ }^{8)}$ の実験データを見直して, 正味の有効剪 断抵抗力の算定式の現地事例への適用性を改善する. さらに，堤体吸出し部の裏込材を玉石に置き換える 吸出し防止実験を行い，粒径を変えるだけによる吸 出し防止効果の有効性も確認する.

\section{（1）洗掘の再現実験}

\section{a）実験装置}

図-4 に示すように，幅 $0.5 \mathrm{~m} \times$ 高さ $0.8 \mathrm{~m} \times$ 全長 $22 \mathrm{~m}$ の二次元造波水路（反射吸収式）に，砂層と表法コ ンクリート被覆, 天端と裏法アクリル板被覆の堤防 模型を設置し, 表法根元の矢板下端から $1.6 \mathrm{~cm}$ 離し て間隙水圧計を設置し，吸出し実験を実施した。

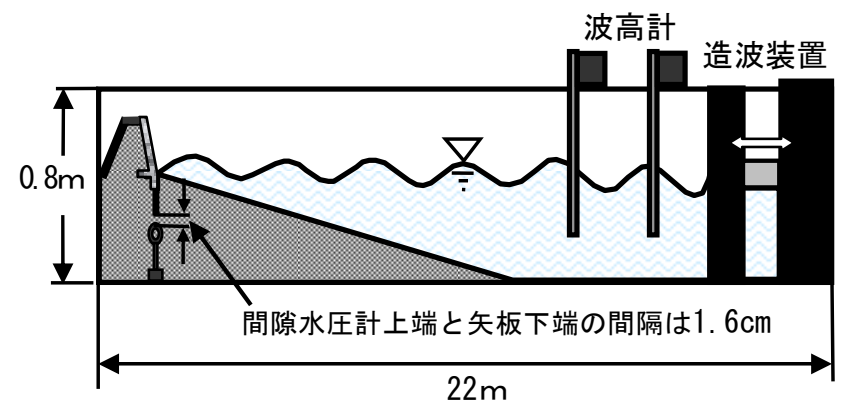

図-4 実験装置の説明図

\section{b）実験方法}

山本・南 ${ }^{8)}$ の研究では, 平成9年台風 9 号による静 岡市広野海岸堤防の被災再現実験から吸出しの再現 性を確認した後に，日本での年 1 回来襲有義波高 $6 \mathrm{~m}$ 〜 $7 \mathrm{~m}$ をフルード則で $1 / 30$ に縮小し，堤体内と底質の 粒径として国内でよく見かける0.5〜2mm程度の砂を 選び，伊藤・土屋 ${ }^{9)}$ の底質に関する相似則を当ては めて，粒径の縮小スケールを $1 / 3$ （換算粒径は 0.20 〜0. $66 \mathrm{~mm})$ とした実験を行っている. そして，堤体 内への侵入波は先行した波の戻り流れの影響を強く 受けることと, 砂層内での侵入波と戻り流れの間隙 水圧を分離することは非常に難しいことから，規則 波による実験も行っている。また，全ケースで，堤 防模型の側面等の全ての隙間には防水剂を充填して, 水と裏込め材が逃げ出さないようにしてあった。

\section{c）実験結果}

図-5は山本・南 ${ }^{8)}$ による実験結果の一例である.

図-5に示されるように，波が作用し始めると共に 前面洗掘が始まり，40分後には前面洗掘が矢板下端 まで進み，土砂の吸出しが無視できなくなってきた。 それにより堤体内部の土砂が矢板下端から外側へ移 動し，堤体内の上部の空隙が大きくなってきた． 2 時間後（フルード則による実時間換算では，11時間 後）には堤体内の $2 / 3$ の土砂が矢板下端から吸出さ れて,「死に体」となった。広野海岸でも半日後に は同様な洗掘・吸出し状態になり, 次の台風来襲時 に簡単に大破した。

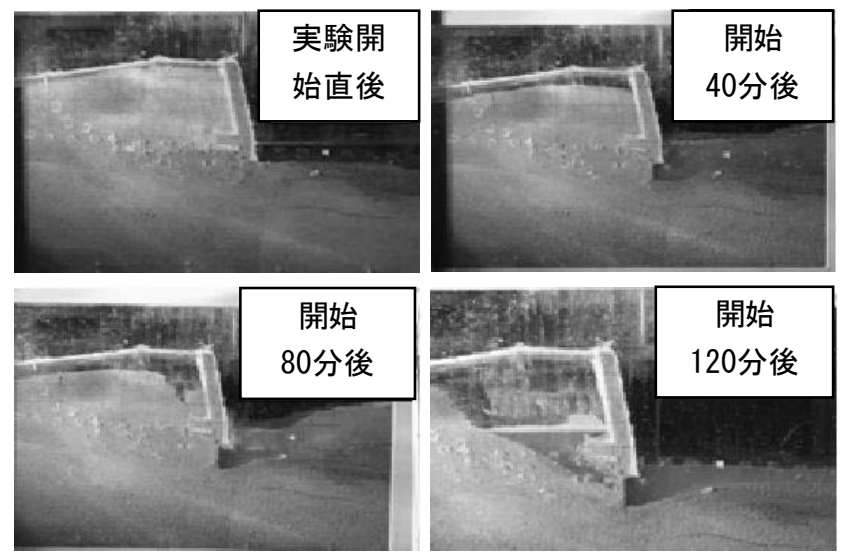

図-5 洗掘被災事例の再現実験例

（2）吸出しの判定モデルの改良

a）吸出し判定モデル

山本・南 ${ }^{8)}$ は，吸出しが発生し，堤体内が空洞化 するかどうかを判定する方法として, 土質力学の静 的安定理論を戻り流れ時の最大剪断力と有効剪断抵 抗力に適用している。すなわち, 前法面と天端を不 透過材で被覆されている堤防や護岸の吸出しに対す る安定性は, 前面矢板下端の吸出し部での, 戻り流 れ時の有効剪断抵抗力 $\tau_{R}$ と最大剪断力 $\tau_{F}$ の差（正 味の有効剪断抵抗力）で決まり，式(1), 式(2)の状 態になると考えた。

$$
\begin{array}{ll}
\text { 原則的に非破壊 : } & \tau_{R}-\tau_{F}>0 \\
\text { 半破壊 全壊 : } & \tau_{R}-\tau_{F}<0
\end{array}
$$

有効剪断抵抗力と最大剪断力を求める式は次のよ うである。

砂の有効剪断抵抗力は次式から求められる.

$$
\tau_{R}=\left\{\left(\rho_{s}-\rho_{w}\right) g d-p_{o b}\right\} \tan \phi
$$

ここで, $\rho_{s}$ は砂層の密度 $\left(=1800 \mathrm{~kg} / \mathrm{m}^{3}\right), \quad \rho_{w}$ は海水 の密度 $\left(=1030 \mathrm{~kg} / \mathrm{m}^{3}\right), \quad g$ は重力加速度, $d$ は堤体前 面の地表面から矢板下端までの砂層厚 $(\mathrm{m}), p_{o b}$ は 矢板下端における戻り流れ時の過剩間隙水圧（動的 間隙水圧）の最大值， $\phi$ は内部摩擦角（砂質土な らば30度）である。

最大剪断力は次式から求められる.

$$
\begin{aligned}
\tau_{F} & =\frac{f}{2} \rho_{w} v^{2} \\
v^{2} & =\frac{2 p_{o b}}{C \rho_{w}}
\end{aligned}
$$

ここで, $f$ は剪断力係数, $v$ は戻り流れ時の最大流 速, $C$ は戻り流れ時の流体力係数である. 


\section{b）過剩間隙水圧算定式の改良}

有効剪断抵抗力を知るためには, 戻り流れ時の矢 板下端部での最大過剩間隙水圧を知る必要がある.

山本・南 ${ }^{8)}$ は堤防前面の入射波高 $H$ を用いて $\rho_{w} g H \times \tanh (0.03 H / d)$ に比例する式を提案した が，その式では $\tanh (0.03 H / d)$ が 1 に近い範囲 で過大な值を与えることから，図-6に示す彼らの実 験データを見直して，式(6)を提案する。

$$
\frac{p_{o b}}{\rho_{w} g H}=0.68\left[\tanh \left(\frac{0.03 H}{d}\right)\right]^{0.6}
$$

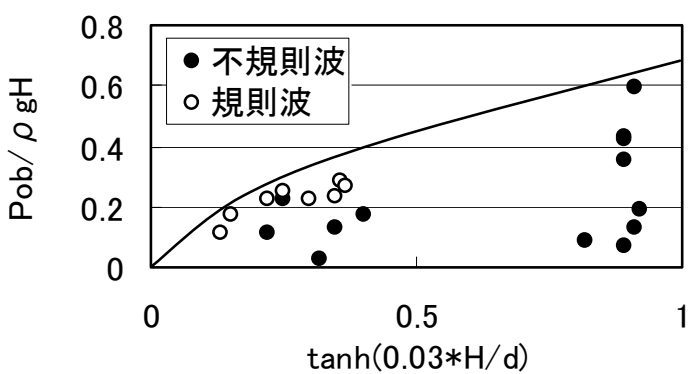

図-6 戻り流れ時の最大過剩間隙水圧と無次元波高と の関係

\section{c）流体力係数算定式の改良}

最大剪断力を知るためには，戻り流れ時の矢板下 端部での流体力係数を知る必要があり, 山本・南8) は矢板下端までの水深 $h$ を用いて, $h / H$ に比例す る式を提案したが，実際の海岸では矢板下端までの 水深がゼロまたは負の值になる場合のあることが分 かったので，図-7に示寸彼らの実験データを見直し て, 式(7)を提案する.

$$
C=\left(\frac{h}{H}+1.0\right)^{1.11}
$$

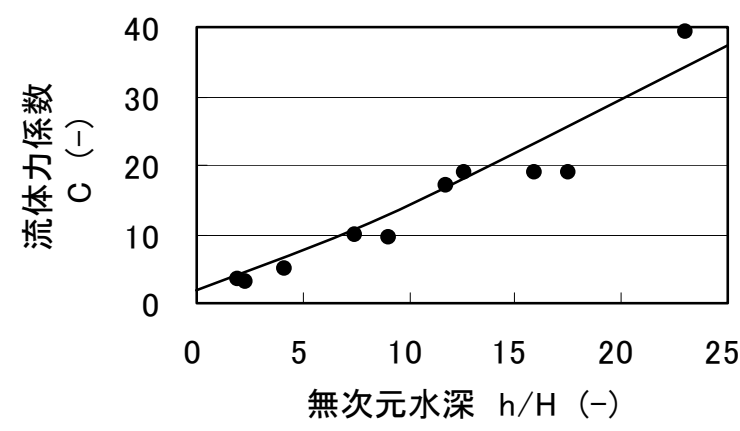

図-7 流体力係数と無次元水深との関係

\section{（3）現地海岸被災実態データへの適用}

表-1にまとめた国内とタイ国の被災実態データを 用いて，式(1)〜式(7)に当てはめて得られた結果を 図-8に示す.ここで，剪断力係数には $f=1$ を用 い，越波量の算定には山本・堀川 ${ }^{10)}$ の式を用いた。 図中の横軸 $\mathrm{O}$ の位置の縦線は, 堤防の吸出しに対寸
る安定性の境界線である。吸出しが素因で壊れた ケースは，この縦線左側領域に分布しており，越波 量が大きくなるほじ，破壊の程度がひどくなってい る。縦線右側領域でも壊れたケースがあるが，これ らは越波量が左側領域に比べて大きく，表-1の被災 機構との対応から，主に波力によって壊れたことが 分かる。そして, 越波量が $0.05 \mathrm{~m}^{3} / \mathrm{m} / \mathrm{s}$ 超えると, 吸出しに関係なく壊れる可能性が高くなると言える。 ただし，現地海岸データの式(6) と式(7)への適用 では，堤防・護岸前面から換算沖波波高の 5 倍ほど 沖側位置での入射有義波高を用いている。この理由 は，高波来襲時は危険であるから，浅い水深で埋め 戻しが起きてしまった高波終了後に測量している場 合が多いため, 前面水深データが破壊時の最深值を 示していないことが少なくないことと，合田の波圧 算定式を用いるときの考え方によった.

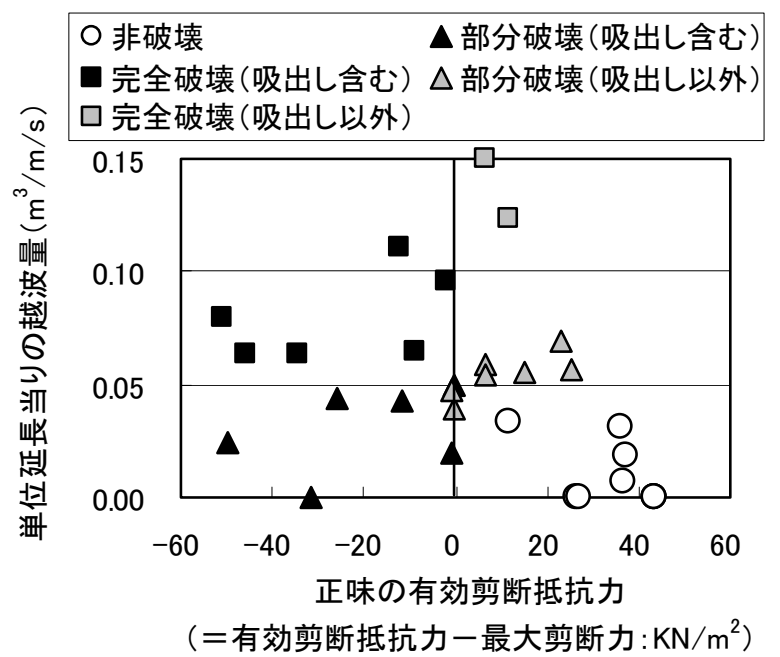

図-8 海岸堤防・護岸の破壊に関する 正味の有効剪断抵抗力と越波量の関係

\section{（4）裏込め材に小石を用いた場合の検討}

式(3) から，戻り流れ時の過剰間隙水圧を小さく するか，内部摩擦角を大きくすれば，吸出しに対す る抵抗力を高められるから, 山本・南 ${ }^{8)}$ は直径が 1 $\mathrm{cm}$ 程度の砕石を図-5の吸出し部へ充填した実験を行 い, 過剩間隙水圧の大幅な低下と内部摩擦角の増加 から良好な吸出し防止効果を得られることを示した。

今回, 同模型で直径が $1 \mathrm{~cm}$ 程度の玉石を吸出し部 に充填した実験を行った。この場合も良好な吸出し 防止効果を得た。測定し読み取った戻り流れ時の過 剩間隙水圧と無次元砂層厚データを元に，戻り流れ 時の過剩間隙水压の算定式を求めると次のように なった。

$$
\frac{p_{o b}}{\rho_{w} g H}=0.3\left[\tanh \left(\frac{0.03 H}{d}\right)\right]^{0.1}
$$

式（6）と式（8）との比較から分かるように，裏 込め材が砂の場合に比べて, 玉石の場合は過剩間隙 水圧が相当に小さくなっていることが判る. 


\section{4. 主要な結論}

以下に主要な成果をまとめる.

a) 日本とタイ国での海岸被災実態調查を行い付録 に示す一覧表を作成した。 それを基に，図-1,2,3を 作図した。これらの図において，黒丸の分布域では 被災する可能性が極めて高い。そして，コンクリー

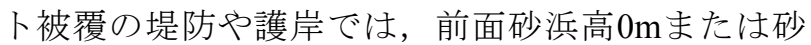
浜幅 $0 \mathrm{~m}$ の場合でも有義波高 $1.5 \mathrm{~m}$ 程度まで, 前面砂 浜高×砂浜幅 $/ 2$ が $0 \mathrm{~m}^{2}$ の場合でも有義波高×波長が $100 \mathrm{~m}^{2}$ 程度までならば被災しにくいことが判った。

b) 海岸堤防・護岸の表のり面に亀裂が無くても, 前面洗掘が進み前面砂浜厚が薄くなってくると, 前 面矢板下端からの吸出しによる空洞化が進み“死に 体”となる。この吸出しは矢板下端部での戻り流れ 時の正味の有効剪断抵抗力が分かれば予測できる. 本研究では現地海岸に適用出来る正味の有効剪断抵
抗力の算定法を提案できた。本算定法を現地海岸に 適用したところ図-8を得た。本図より, 正味の有効 剪断抵抗力が負の場合は, 吸出しが生じるため, 越 波量が小さくても被災し，同抵抗力が正の場合は越 波量が $0.05 \mathrm{~m}^{3} / \mathrm{m} / \mathrm{s}$ 以上になると，十分に大きな波力 が作用しているため被災するようになる.

謝辞：本研究は文部科学省の科研費 (基盤研究C, 21510197）に負うところ大である。また，モンクッ 卜王工科大学の土木工学科長である Nunthawath Charusrojthanadech准教授にも多大な援助を受けた. これらの援助に対して心からの謝意を表します。

付録

表-1 高波による被災実態調查結果一覧表

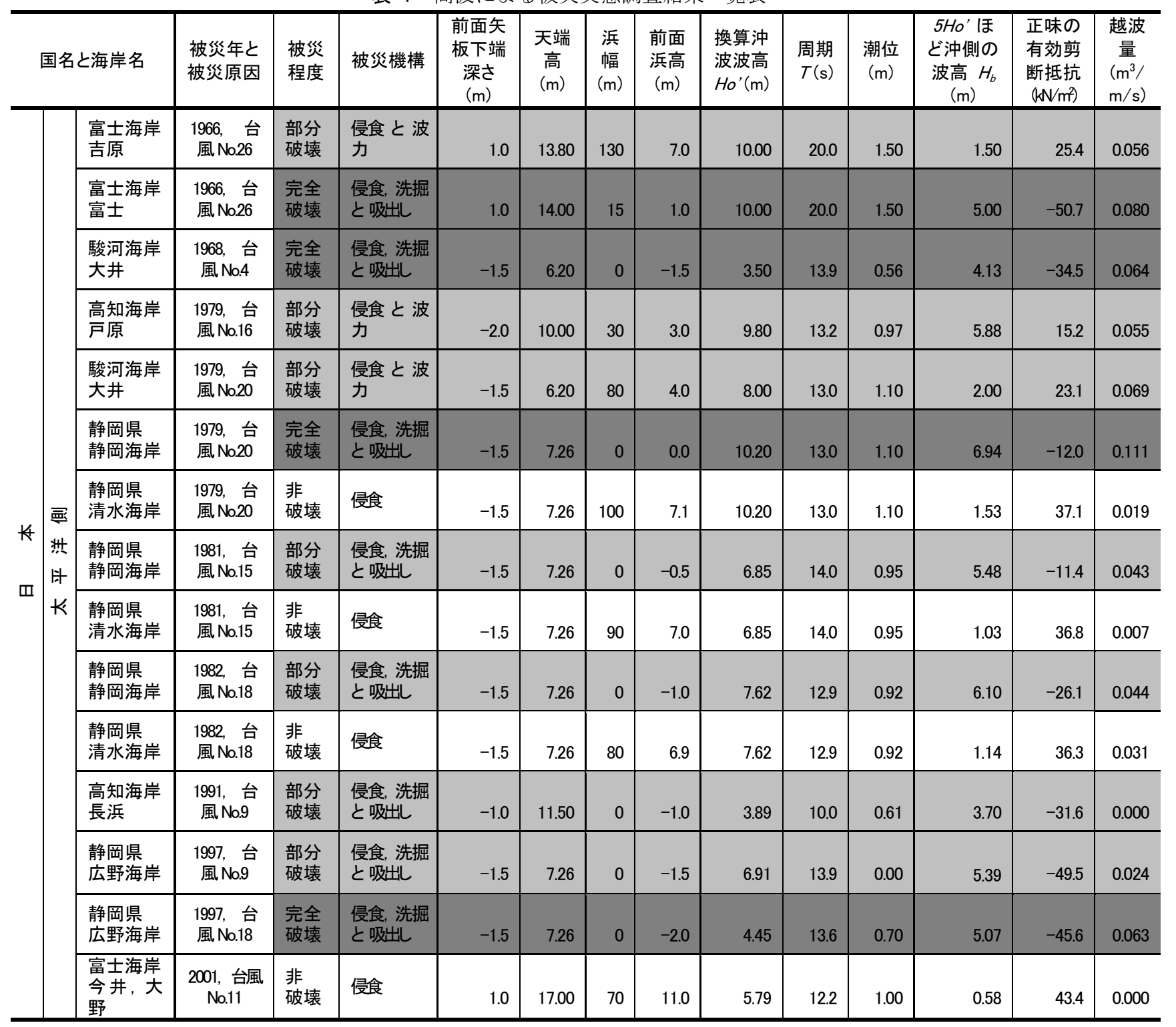




\begin{tabular}{|c|c|c|c|c|c|c|c|c|c|c|c|c|c|c|c|}
\hline \multicolumn{3}{|c|}{ 国名と海岸名 } & $\begin{array}{l}\text { 被災年と } \\
\text { 被災原因 }\end{array}$ & $\begin{array}{l}\text { 被災 } \\
\text { 程度 }\end{array}$ & 被災機構 & $\begin{array}{c}\text { 前面矢 } \\
\text { 板下端 } \\
\text { 深さ } \\
\text { (m) }\end{array}$ & $\begin{array}{c}\text { 天端 } \\
\text { 高 } \\
(\mathrm{m})\end{array}$ & $\begin{array}{l}\text { 浜 } \\
\text { 幅 } \\
\text { (m) }\end{array}$ & $\begin{array}{l}\text { 前面 } \\
\text { 浜高 } \\
(\mathrm{m})\end{array}$ & $\begin{array}{l}\text { 換算沖 } \\
\text { 波波高 } \\
H o^{\prime}(\mathrm{m})\end{array}$ & $\begin{array}{l}\text { 周期 } \\
T(\mathrm{~s})\end{array}$ & $\begin{array}{c}\text { 潮位 } \\
(\mathrm{m})\end{array}$ & $\begin{array}{c}5 H o^{\prime} ほ \\
\text { ど沖側の } \\
\text { 波高 } H_{b} \\
(\mathrm{~m})\end{array}$ & $\begin{array}{l}\text { 正味の } \\
\text { 有効剪 } \\
\text { 断抵抗 } \\
\left(\mathrm{kN} / \mathrm{m}^{2}\right)\end{array}$ & $\begin{array}{c}\text { 越波 } \\
\text { 量 } \\
\left(\mathrm{m}^{3} /\right. \\
\mathrm{m} / \mathrm{s})\end{array}$ \\
\hline \multirow{9}{*}{ K } & \multirow{4}{*}{$\begin{array}{l}\text { 寻 } \\
\text { 莽 } \\
\text { 米 } \\
\text { K }\end{array}$} & $\begin{array}{l}\text { 静岡県御 } \\
\text { 前崎海岸 }\end{array}$ & $\begin{array}{c}2003 \text {, 春 } \\
\text { の時化 }\end{array}$ & $\begin{array}{l}\text { 部分 } \\
\text { 破壊 }\end{array}$ & $\begin{array}{l}\text { 侵食, 洗掘 } \\
\text { と吸出 }\end{array}$ & - & 7.08 & 0 & 0.0 & 5.04 & 10.9 & 0.74 & 3.68 & - & 0.006 \\
\hline & & $\begin{array}{l}\text { 富士海岸 } \\
\text { 今井, 大野 }\end{array}$ & $\begin{array}{c}2004 \text {, 台風 } \\
\text { No.22 }\end{array}$ & $\begin{array}{l}\text { 非 } \\
\text { 破壊 }\end{array}$ & 侵食 & 1.0 & 17.00 & 70 & 11.0 & 5.63 & 12.6 & 1.00 & 0.56 & 43.4 & 0.000 \\
\hline & & $\begin{array}{l}\text { 富士海岸 } \\
\text { 今井, 大野 }\end{array}$ & $\begin{array}{c}2004 \text {, 台風 } \\
\text { No.23 }\end{array}$ & $\begin{array}{l}\text { 非 } \\
\text { 破壊 }\end{array}$ & 侵食 & 1.0 & 17.00 & 70 & 11.0 & 5.35 & 10.6 & 1.00 & 0.27 & 43.5 & 0.000 \\
\hline & & $\begin{array}{l}\text { 高知県な } \\
\text { ばえ海岸 }\end{array}$ & $\begin{array}{l}2004 \text {, 台風 } \\
\text { No.23 }\end{array}$ & $\begin{array}{l}\text { 部分 } \\
\text { 破壊 }\end{array}$ & 波力 & - & 9.80 & 5 & 0.5 & 13.55 & 15.8 & 2.86 & 7.72 & - & 0.045 \\
\hline & \multirow{5}{*}{ 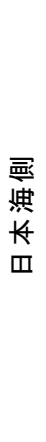 } & $\begin{array}{l}\text { 石川県 } \\
\text { 小松海岸 }\end{array}$ & $\begin{array}{c}\text { 1994, 冬 } \\
\text { 期煈浪 }\end{array}$ & $\begin{array}{l}\text { 部分 } \\
\text { 破壊 }\end{array}$ & $\begin{array}{l}\text { 侵食, 洗掘 } \\
\text { と吸出し }\end{array}$ & -4.0 & 5.40 & 0 & -2.0 & 4.38 & 12.3 & 0.44 & 5.69 & -1.1 & 0.020 \\
\hline & & $\begin{array}{l}\text { 石川県 } \\
\text { 小松海岸 }\end{array}$ & $\begin{array}{c}2000, \text { 冬 } \\
\text { 期煈浪 }\end{array}$ & $\begin{array}{l}\text { 部分 } \\
\text { 破壊 }\end{array}$ & $\begin{array}{l}\text { 侵食, 洗掘 } \\
\text { と吸出し }\end{array}$ & -4.0 & 5.40 & 0 & -2.0 & 6.00 & 10.5 & 0.50 & 5.46 & -0.4 & 0.050 \\
\hline & & $\begin{array}{l}\text { 石川県 } \\
\text { 小松海岸 }\end{array}$ & $\begin{array}{c}\text { 2001, 冬 } \\
\text { 期風浪 }\end{array}$ & $\begin{array}{l}\text { 完全 } \\
\text { 破壊 }\end{array}$ & $\begin{array}{l}\text { 侵食, 洗掘 } \\
\text { と吸出し }\end{array}$ & -4.0 & 5.40 & 0 & -2.2 & 5.58 & 11.7 & 0.71 & 5.52 & -1.9 & 0.096 \\
\hline & & $\begin{array}{l}\text { 石川県 } \\
\text { 小松海岸 }\end{array}$ & $\begin{array}{l}2001, \text { 台 } \\
\text { 風 No.15 }\end{array}$ & $\begin{array}{l}\text { 完全 } \\
\text { 破壊 }\end{array}$ & $\begin{array}{l}\text { 侵食, 洗掘 } \\
\text { と吸出し }\end{array}$ & -2.5 & 5.40 & 0 & -1.5 & 6.00 & 10.5 & 0.58 & 5.10 & -8.9 & 0.065 \\
\hline & & $\begin{array}{l}\text { 富山県 } \\
\text { 入善海岸 }\end{array}$ & $\begin{array}{c}2008 \text {, 冬 } \\
\text { 期禹浪 }\end{array}$ & $\begin{array}{l}\text { 完全 } \\
\text { 破壊 }\end{array}$ & $\begin{array}{l}\text { 侵食, 洗掘 } \\
\text { と波力 }\end{array}$ & -3.5 & 5.70 & 0 & 0.0 & 9.92 & 16.1 & 0.21 & 6.35 & 6.3 & 0.151 \\
\hline \multirow{8}{*}{$\begin{array}{l}\text { 国 } \\
r \\
5\end{array}$} & \multirow{8}{*}{ 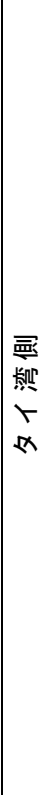 } & $\begin{array}{l}\text { Chao Phraya } \\
\text { 川河口 }\end{array}$ & $\begin{array}{l}\text { 雨期モン } \\
\text { スーン }\end{array}$ & $\begin{array}{l}\text { 部分 } \\
\text { 破壊 }\end{array}$ & $\begin{array}{l}\text { 侵食 と 波 } \\
\text { 力 }\end{array}$ & -1.0 & 2.00 & 0 & -0.5 & 2.50 & 6.1 & 1.54 & 1.63 & -0.4 & 0.039 \\
\hline & & $\begin{array}{l}\text { Khlong Dan } \\
\text { 海岸 }\end{array}$ & $\begin{array}{l}\text { 雨期壬 } \\
\text { スーン }\end{array}$ & $\begin{array}{l}\text { 部分 } \\
\text { 破壊 }\end{array}$ & $\begin{array}{l}\text { 侵食 と 波 } \\
\text { 力 }\end{array}$ & -0.6 & 2.00 & 0 & -0.1 & 2.50 & 6.1 & 1.73 & 1.68 & -0.6 & 0.047 \\
\hline & & $\begin{array}{l}\text { Wam } \\
\text { ビーチ }\end{array}$ & & $\begin{array}{l}\text { 非 } \\
\text { 破壊 }\end{array}$ & & - & 2.40 & 30 & 2.4 & 2.00 & 6.1 & 1.40 & 0.10 & - & 0.012 \\
\hline & & $\begin{array}{l}\text { Pattaya } \\
\text { ビーチ }\end{array}$ & & $\begin{array}{l}\text { 非 } \\
\text { 破壊 }\end{array}$ & & -3.5 & 3.50 & 20 & 2.6 & 2.25 & 6.1 & 1.40 & 0.23 & 26.6 & 0.000 \\
\hline & & $\begin{array}{l}\text { Jomthien } \\
\text { ビ—チ }\end{array}$ & & $\begin{array}{l}\text { 非 } \\
\text { 破壊 }\end{array}$ & & -3.5 & 3.40 & 20 & 2.7 & 2.50 & 6.1 & 1.40 & 0.50 & 27.0 & 0.000 \\
\hline & & $\begin{array}{l}\text { Sangchan } \\
\text { ビーチ }\end{array}$ & $\begin{array}{l}\text { 1997. 台風 } \\
\text { Linda }\end{array}$ & $\begin{array}{l}\text { 完全 } \\
\text { 破壊 }\end{array}$ & $\begin{array}{l}\text { 侵食 と 波 } \\
\text { 力 }\end{array}$ & -1.0 & 2.40 & 30 & 1.8 & 3.75 & 6.2 & 1.17 & 1.13 & 11.7 & 0.123 \\
\hline & & $\begin{array}{l}\text { Chao Lao } \\
\text { ビ—チ }\end{array}$ & $\begin{array}{c}\text { 雨期壬 } \\
\text { スーン }\end{array}$ & $\begin{array}{l}\text { 部分 } \\
\text { 破壊 }\end{array}$ & $\begin{array}{l}\text { 侵食 と 護 } \\
\text { 岸劣化 }\end{array}$ & -1.5 & 3.10 & 5 & 0.5 & 2.80 & 6.5 & 1.14 & 2.24 & 6.7 & 0.059 \\
\hline & & $\begin{array}{l}\text { Leam Sadet } \\
\text { ビーチ }\end{array}$ & $\begin{array}{c}\text { 雨期牛 } \\
\text { スーン }\end{array}$ & $\begin{array}{l}\text { 部分 } \\
\text { 破壊 }\end{array}$ & $\begin{array}{l}\text { 洗掘 と 波 } \\
\text { 力 }\end{array}$ & -1.5 & 2.50 & 5 & 0.5 & 2.80 & 6.5 & 1.14 & 2.24 & 6.7 & 0.054 \\
\hline
\end{tabular}

\section{参考文献}

1) 大河原満・橋本宏・斉藤雄三郎：被災事例から見た海 岸堤防・護岸に関する一考察, 第 30 回海講論文集, pp. 264-268, 1983.

2) 岩崎複久 ・ 田中茂信 - 佐藤愼司 - 名合宏之・前野詩 朗・小谷裕司：海岸堤防の空洞化発生機構に関する実 験的研究, 海工論文集, 第 42 巻, pp. 1026-1030, 1995.

3) 山本吉道・川島理・福濱方哉：高波と津波による海岸 施設の破壊機構と破堤限界值の現地海岸適用, 海工論 文集，第 52 巻，pp. 1281-1285， 2005.

4）善功企 : 海底地盤の波浪による液状化に関する研究, 港湾技研資料, No.755, 112p. , 1993.

5) 加藤史訓・佐藤愼司・田中茂信 : 波浪による海岸堤防 周辺地盤の間隙水圧変動, 海工論文集, 第 43 巻, pp. 1011-1015, 1996.

6) 前野詩朗・小谷裕司・星山知恵 : 変動水圧場における 護岸裏込め土砂の流失限界に関する研究, 海工論文集, 第 47 巻, pp. 926-930, 2000.

7）中村友昭・許東秀 - 水谷法美：捨石護岸背後の埋立土 砂の吸い出し機構，土木学会論文集 B, Vol.62, No. 1, pp. 150-162, 2006.

8) 山本吉道・南宣孝：高波による海岸堤防破壊メカニズ 厶の実験的研究, 土木学会論文集 B2, Vol. B2-65, pp. 901-905, 2009.

9) 伊藤政博 - 土屋義人：二次元海浜変形の相似則につい て，土木学会論文集，第 357 号 / II -3, pp. 177-186, 1985.

10) 山本吉道・堀川清司 : 新しい越波量算定式の提案，海 洋開発論文集，Vol.7，pp. 25-30，1991. 